\title{
Presumptive Adaptation and the Effectiveness of Knowledge Transfer
}

Robert J. Jensen

robertjensen@byu.edu

Gabriel Szulanski

Follow this and additional works at: https://scholarsarchive.byu.edu/facpub

Part of the Business Administration, Management, and Operations Commons

\section{Original Publication Citation}

Szulanski, G., Jensen, R.J. 26. Presumptive Adaptation and the Effectiveness or Knowledge Transfer. Strategic Management Journal 27 (1): 937-957. http://onlinelibrary.wiley.com/journal/ $1.12 / \% 28 I S S N \% 29197-266$

\section{BYU ScholarsArchive Citation}

Jensen, Robert J. and Szulanski, Gabriel, "Presumptive Adaptation and the Effectiveness of Knowledge Transfer" (2006). Faculty Publications. 293.

https://scholarsarchive.byu.edu/facpub/293

This Peer-Reviewed Article is brought to you for free and open access by BYU ScholarsArchive. It has been accepted for inclusion in Faculty Publications by an authorized administrator of BYU ScholarsArchive. For more information, please contact ellen_amatangelo@byu.edu. 


\title{
PRESUMPTIVE ADAPTATION AND
}

\section{THE EFFECTIVENESS OF KNOWLEDGE TRANSFER}

\author{
Gabriel Szulanski \\ INSEAD \\ Department of Strategy and Management \\ Ayer Rajah Avenue \\ 138676 Singapore \\ Tel : (65) 67995388 \\ Fax: (65) 67995399 \\ e-mail: gabriel.szulanski@insead.edu
}

\section{Robert J. Jensen}

Marriott School, Brigham Young University

Department of Organizational Leadership and Strategy

783 TNRB

Provo, UT 84602

Tel: (801) 422-4413

e-mail: robertjensen@byu.edu

\section{Key Words: Knowledge Transfer, Adaptation, Quasi-Experiment, International, Franchise Running Header: Presumptive Adaptation}

This paper is dedicated to the memory of Sumantra Ghoshal. Sumantra challenged us to find a way to test a theory with a case study, the proverbial $\mathrm{n}=1$, in a scholarly way. He, alongside a formidable cast of other clinical researchers, felt that in-depth case studies could potentially offer comparable 'power' to test theories as did large $\mathrm{n}$ datasets. They did not know quite how to do it, at least not in a way that would be acceptable to a wide community of strategy researchers. However they made us believe that it was possible.

This paper is the answer to that challenge, a challenge that marks the beginning of a serendipitous path where dots first emerged and then connected to provide the answer. The dots included field research that was "lived forward but understood backward", the re-discovery of the repeated-treatment quasi-experimental research design, and a story line that in hindsight turned out to be a fantastic natural experiment.

We owe more than we can detail. We gained phenomenal access to the story thanks to the generosity of Albert Alhadef who introduced us to the fascinating world of Mail Boxes Etc. He, and later Peter Holt, Kurt Ullman, Carlos Martinez, and Alfonso Vilches, all of them from the MBE International Office, helped us explore the phenomena with no strings attached. Mike Casaburi and Tanya Lee provided invaluable research support. The Reginald Jones Center, the Mack Center, and the University Research Foundation of the University of Pennsylvania provided generous research support.

We owe especially to Sid Winter who was both intellectually and literally a chaperon during the lengthy investigation. He is a full partner in the development of the ideas behind this paper and in the field work. His enthusiasm kept us going at times when we despaired.

Finally, we are indebted to Will Mitchell and two anonymous referees for a fantastic, constructive, incisive, and uncompromising review process. 


\title{
PRESUMPTIVE ADAPTATION AND \\ THE EFFECTIVENESS OF KNOWLEDGE TRANSFER
}

\begin{abstract}
Adaptation almost invariably accompanies the cross-border transfer of firm specific practices. The existing literature contains two conflicting approaches to adaptation. The first, more traditional approach, following institutional, motivational, and pragmatic efficiency considerations, presumes that a modified practice can be fine tuned, stabilized, and institutionalized without consulting a working example and that practices should thus be adapted as quickly as possible to create fit with the local environment. The second approach argues, instead, for the need to maintain the diagnostic value of the original practice by adapting cautiously and gradually. In this paper, we report an in-depth field investigation of the relationship between presumptive adaptation, adaptation that removes the diagnostic value of the original practice, and transfer effectiveness. The setting is the transfer of franchising knowledge across borders. We investigate how adherence to recommended practices affects the rate of network growth in the host country. We find that presumptive adaptation stalls network growth while a conservative approach to adaptation, which basically entails close adherence to the original practice, results in remarkably rapid network growth. We conclude that presumptive adaptation of knowledge assets could be detrimental to performance.
\end{abstract}




\section{PRESUMPTIVE ADAPTATION AND THE EFFECTIVENESS OF KNOWLEDGE TRANSFER}

Empirical evidence confirms that some degree of adaptation almost invariably accompanies the cross-border transfer of firm-specific practices (Onkvisit \& Shaw, 1987). For example, both human resource and marketing practices have been found to vary widely within firms across national boundaries ( Douglas \& Wind, 1987; Robert, Probst, Martocchio, \& Drasgow, 2000; Rosenzweig \& Nohria, 1994). However, this raises the question of how units are affected by the adaptation; indeed, there are conflicting rationales concerning the appropriate approach to conducting successful adaptations of organizational practices.

One approach relies on institutional (Kostova \& Roth, 2002), motivational (Morosini, Shane, \& Singh 1998), and pragmatic efficiency considerations which suggest that the organizational practices should be adapted as quickly as possible to closely match local environmental characteristics (Bartlett \& Ghoshal, 1989; Prahalad \& Lieberthal, 1998). This typically involves significant changes to multiple aspects of the practice. The alternative approach notes the complexity and causal ambiguity inherent in most practices (Rivkin, 2000) as well as ex-ante uncertainty as to the relevant environment (Westney, 1987; Penrose, 1959; Leonard-Barton, 1988) and suggests the need to preserve the diagnostic value of the original practice (Jensen \& Szulanski, 2005; Winter \& Szulanski, 2001), indicating that adaptation should proceed cautiously and gradually in carefully designed steps that ideally involve only a single change at a time.

Extensive adaptations, involving two or more simultaneous changes, are based on the presumption that the modified practices can be fine-tuned, stabilized and institutionalized 
without referring back to a working example. When this presumption is true, such adaptations enhance the effectiveness of knowledge transfer. However when this is not true, presumptive adaptation may severely degrade effectiveness.

In this paper we report a naturally occurring, repeated-treatment quasi-experiment that isolates the effect of presumptive adaptation on transfer effectiveness. The setting is Mail Boxes Etc. (MBE) in Israel. MBE (now the UPS Store) is the largest non-food franchise organization in the world, with over 3,900 outlets in the U.S. and over 1,100 outside of the U.S. The investigation covers the period from August 1995, when the MBE franchise network in Israel was established, until July 2001. We systematically document how the approach to adaptation (presumptive or otherwise) affects network growth.

We begin by discussing the theory behind presumptive adaptation and constructing alternative hypotheses about the effects on transfer effectiveness. We then explain the setting and methodology as a preamble to an in-depth account of MBE Israel's approach to adaptation and the observed level of growth of its network. Finally, we evaluate the data in terms of a naturally occurring, repeated-treatment quasi-experiment, concluding with a discussion of the implications of this research on managing efforts to leverage knowledge assets.

\section{THEORY AND HYPOTHESES}

\section{The Need for Adaptation}

One of the central issues in the cross-border transfer of firm-specific resources, including knowledge resources (Kostova, 1999; Morosini, Shane, \& Singh, 1998), is whether or not and to what extent the firm should adapt the resources to fit local conditions (Bartlett \& Ghoshal, 1989; Prahalad \& Doz, 1987). Fit with the environment is argued to be essential not only for subsidiary success but also survival (Lawrence \& Lorsch, 1967; Sorge, 1991) and streams of literature in 
organizational theory (Kostova, 1999; Kostova \& Zaheer, 1999; Scott, 2001), international business (Bartlett \& Ghoshal, 1989; Griffith Hu, \& Ryans, 2000; Nohria \& Ghoshal, 1997; Prahalad \& Doz, 1987), and international marketing (Cui \& Liu, 2001; Yan, 1994) have suggested that adaptation is necessary in order to ensure fit with the relevant characteristics of the local environment, which typically differ from those in the source environment along a number of critical institutional and market dimensions.

\section{The Presumptiveness of Significant Adaptation}

While it is sensible that the subsidiary, and hence transferred practices that it uses, must achieve fit with the local environment, focusing solely on fit creates a potential dilemma. Specifically, conventional wisdom often assumes that transferred practices are fully understood and transferred without difficulty. This may be true for relatively simple practices, however, many practices are at least moderately complex (Rivkin, 2000) and/or causally ambiguous (Lippman \& Rumelt, 1982). As a result, even with experience neither the multinational firm (MNC) nor the subsidiary may fully understand the practice nor be able to completely codify it, making it sticky, or difficult, to transfer (Szulanski, 1996; von Hippel, 1994).

This complicates the adaptation process making any adaptation at least somewhat presumptive. This is particularly true for significant adaptations, those containing two or more simultaneous, discrete changes, because such changes complicate the cause and effect relationship exponentially. This makes it difficult to attribute specific effects to their specific alterations and creates potential unforeseen interactions between the adapted and un-adapted components and between the modified components themselves. In addition, there may be unforeseen interactions, even for experienced local managers (Westney, 1987), between the 
practice and the relevant host environment as the relevant and the anticipated environments often differ due to incomplete information, and to mutual adaptation between the practice and the relevant environment (Leonard-Barton, 1988; Penrose, 1959; Burgelman, 1983). Such problems, moreover, are likely to extend to any significant adaptation effort, even those occurring posttransfer.

Indeed, if any significant adaptation effort is to succeed, one must presume that the implemented practice can be made to work despite the diminished capacity, or even loss, of the original as a referent. Following this line of thinking, we define as presumptive any adaptations involving two or more simultaneous changes that are of sufficient magnitude to render the template site, or previously working version of the practice, of little diagnostic value.

\section{Presumptive Adaptation and Transfer Effectiveness}

Current literature regarding presumptive adaptation takes two opposing stances: (1) that presumptive adaptation will increase the performance of the subsidiary implementing the practice and (2) that presumptive adaptation will decrease the performance of the subsidiary implementing the adapted practice.

Presumptive Adaptation Increases Subsidiary Performance. The traditional literature addressing the adaptation of firm-specific assets implies that anticipating the relevant characteristics of the local environment is the most critical aspect of successfully transferring firm assets to local subsidiaries (Bartlett \& Ghoshal, 1989; Prahalad \& Doz, 1987). This argument is explicit in recent work focusing specifically on the transfer of organizational practices. For instance, concerning human resource practices, significant adaptation is explicitly argued to increase acceptance of the knowledge being transferred. A practice that is adapted 
comprehensively to match cognitive and normative institutions presumed relevant in the host environment becomes both more understandable and more acceptable to the local labor force responsible for its implementation (Griffith et al., 2000; Kirkman, Gibson, \& Shapiro, 2001; Kostova \& Roth, 2002; Luo, 2000; Morosini et al., 1998).

For a modified practice to be understood and accepted, however, substantial adaptations must usually occur sharply, either in a single step or within a relatively narrow window (Tyre \& Orlikowsky, 1994). Creeping, gradual adaptation is typically resisted (Tolbert \& Zucker, 1983). Thus, traditional arguments presume that the need for quick fit with the environment is more important than comparability with the template, or original practice. The idea that increased implementation is due to closer fit leads to the stance that presumptive adaptation will result in a greater ability to transfer organizational practices and hence, increased subsidiary performance.

\footnotetext{
Hypothesis 1a: Ceteris paribus, presumptive adaptation will enhance subsidiary performance.
}

Presumptive Adaptation Decreases Subsidiary Performance. In opposition to traditional literature, however, an increasing number of observations from actual transfers of organizational practices show that firms increasingly shun drastic departures from existing practices. In fact, these firms often postpone most modifications until after adequate experience has been gained with the original practice in the host environment or until comparable results are obtained, with incremental adaptations of selected aspects of the practice occurring thereafter (Financial Times, 1997; Great Harvest Bread, 1999; McDonald, 1998). This anecdotal evidence raises questions about the desirability of presumptive adaptation. 
In most transfers of practices, the implementation of the practice at the recipient site is typically an iterative process where the original template site or working example is used as a reference to diagnose and solve problems that arise at the recipient site during transfer and implementation (Gielens \& Dekimpe, 2001; Jensen \& Szulanski, 2005; Winter \& Szulanski, 2001). Presumptive adaptation, whether it occurs at the time of a transfer or later, by definition involves alterations of sufficient magnitude that the comparability between the modified practice and the original is reduced, thus diminishing the value of the original practice as a referent when diagnosing and solving problems in the new setting. Presumptive adaptation thus rejects the information value of the template presuming instead that implementation, due to a close fit with the environment, will occur smoothly enough that the practice can be transferred without reference. However, if the transfer does not occur smoothly, presumptive adaptation may severely degrade the performance of the implemented practice leading to poorer subsidiary performance.

Hypothesis 1b: Ceteris paribus, presumptive adaptation will hamper subsidiary performance.

\section{METHODS}

\section{Setting}

Franchising. The general setting for our study is multinational franchising. Multinational franchise organizations, as a subset of MNCs, are particularly interesting settings to study presumptive adaptation. Because they serve individual customers they are subject to strong pressures for local adaptation. Moreover, transferring knowledge across international borders increases the variance of adaptation choices due to amplified isomorphic forces which increase the impetus to adapt (Sorge, 1991). In addition, multinational franchise organizations, are well 
suited for studying issues of organizational knowledge transfer (Nelson \& Winter, 1982) because they compete primarily through growth, first by increasing the number of outlets during the expansion phase and then, once the network has reached the carrying capacity of its environment, by managing same store revenue growth through the replication of best practices. For both forms of growth, the transfer of knowledge between geographic locations plays an important role. This allows us to more clearly observe the incidence of decisions concerning presumptive adaptation.

Furthermore franchise organizations operate across an arms length interface with their franchisees and cannot completely enforce how these franchisees receive and use the knowledge being transferred (Bradach, 1998; Kaufmann \& Eroglu, 1998), with rescission of such agreements being a dramatic, costly, and undesirable event. Enforcement is even less likely between franchisors and Master Licensees (MLs), the people who purchase the right to develop a network for an exclusive geographic territory, because deviations from the type of knowledge transferred to MLs are often more tacit and less critical for the identity of the brand. This allows for greater variation in adaptation decisions than one might find in company owned stores or subsidiaries where the company can resort to fiat to enforce compliance with a particular set of practices (Williamson, 1975). The greater the variation in adaptation decisions the higher the incidence of presumptive adaptation is likely to be, making transfers of organizational practices within multinational franchising ideal for our study.

Mail Boxes Etc. in Israel. The specific setting of our study is the Mail Boxes Etc. (MBE) franchise system in Israel. MBE, the largest non-food franchisor in the world, was first launched in 1980 in San Diego, California in an effort to fill a need for postal services. MBE specializes primarily in services for the small office and home office environments, including 
photocopying, color copying, packing and shipping, parcel and express courier, complete mailbox service, Internet access, and office and packing supplies. In 1986, when it went public, MBE had grown to 250 franchise outlets. Four years later, in 1990, it had grown to over 1000 centers, and, by 1999, had quadrupled again to nearly 4000. After securing a strong foothold in the United States and building a strong foundation of experience, MBE decided, in 1989, to sell master franchise licenses abroad. By $1999 \mathrm{MBE}$ was operating or had licensing agreements in nearly 60 countries with over 700 international outlets.

This study examines the growth of the MBE network in Israel. MBE sold the rights to build the MBE network in Israel to Albert Alhadef in August 1995. Eleven months later Albert opened his first store. As they did with other MLs, MBE provided Albert with substantial knowledge on how to develop an MBE network. This paper will focus exclusively on the transfer of knowledge concerning the task of building an MBE network rather than that of implementing the relatively more codified business concept within an MBE store. ${ }^{1}$

In retrospect, the history of the MBE Israel network could be viewed as a naturally occurring, repeated-treatment quasi-experiment which allows us to make inferences about the effect of presumptive adaptation on subsidiary performance, as measured by the growth in the number of stores in the network. Furthermore, because we were granted complete access to the ML management team, we could double check for emerging interpretations and thus rule out many potential threats to validity when drawing our conclusions. Moreover, focusing on a single

1 We chose to study network growth rather than the operation of individual stores for a number of reasons. First, it enables us to use a repeated-treatment, quasi-experimental research design rather than the non-equivalent groups, post-test only design that the study of individual stores would require. The latter design is substantially weaker in terms of internal validity. Second, while one could potentially overcome the inherent weaknesses of the latter design, it would require a deeper level of access than was available. We had virtually unfettered access to MBE Israel headquarters but had limited access to the individual franchisees, making it impossible to adequately address the threats to validity that arise from the use of a non-equivalent groups post-test only research design. We recognize, however, that adaptation of the business format may also affect network growth. We address this issue at length later in our paper in our discussion of threats to validity. 
network allowed us to keep the environment constant, further enhancing internal validity by eliminating a large class of confounding factors that could cloud the effect of presumptive adaptation.

Relying on a single case, however, substantially increases the challenge of establishing the generalizability of our findings, a challenge we address in two steps. First, we rely on our broad exposure to the MBE internationalization experience to establish that the case of MBE Israel is indeed representative of, and applicable to, other contexts within MBE. Second, we argue that the case study serves as a potent counterexample to the seemingly pervasive conviction that presumptive adaptation is generally desirable. The lessons we draw from this example about the possible ineffectiveness of presumptive adaptation cannot be easily dismissed, given the similarity of MBE's knowledge transfer processes with those occurring in other firms and, especially, in franchise organizations.

\section{Data Collection}

We followed Yin (1989) concerning data collection, employing a descriptive case study methodology during this stage of the research. Data collection occurred primarily through a series of interviews with all of the relevant managers and employees at MBE headquarters and MBE Israel as well as through extensive archival data gathering in both locations. After signing a comprehensive confidentiality agreement, we had complete access to and cooperation from both locations. In all cases the interviews were semi-structured and aimed at uncovering the role of the ML, the knowledge transfer process, and the difficulties of expanding a franchise network overseas, specifically focusing on the balance between following the approach recommended by headquarters for developing a network versus creating one that is adapted to local needs. A 
description of the type and number of interviews is included in Appendix A. The CEO at MBE Israel during the period of observation also completed a lengthy questionnaire as part of a wider, but connected study. Monthly e-mails and telephone conversations occurred prior to and following the on-site visits during the entire period of observation. The period of time tracked in the field investigation is 1995 to 2001.

The data collection occurred in real time, negating any retrospective bias and involved triangulation, enhancing the validity of the descriptions. To minimize observer effects, we were careful not to intervene and offered no opinions or suggestions to the participants. The following two sections detail how we measured presumptive adaptation and the growth of the network.

Presumptive Adaptation. We define presumptive adaptation as a significant adaptation intended to create fit with the local environment. Significant is defined as the simultaneous modification of two or more components of the original practice. We operationalize it as nonconformity to a standard approach following a method pioneered by Westphal, Gulati and Shortell (1997), as explained below.

Establishing Intentional Departure from the Standard Approach. In line with Westphal, et al. (1997), we establish non-conformity using both qualitative and quantitative indicators. Westphal, et al. (1997) measure qualitatively the intention to conform through a self-reported declaration of conformity to a "particular, standard ... model" (p. 378). Accordingly, we verify the existence of an intention to depart from the standard approach through interviews with the MBE Israel management team and external observers (e.g., corporate liaisons). We asked general questions about the process that MBE Israel was going through in establishing an MBE network in Israel. As the participants brought up issues of adaptation, we probed the rationale underlying the adaptation in addition to determining when and how the adaptation had occurred. 
To establish the degree of conformity (or lack thereof) to the standard approach, we adapted the quantitative measure of conformity established by Westphal, et al. (1997). Their measure is computed by breaking up a policy into its constituent practices and building a vector of implemented practices to determine the percentage of practices that are actually implemented. We utilize the same method, but rather than computing the percentage in relation to the number of other units implementing the practices, we compute the raw number of constituent practices implemented and compare that number to the standard approach recommended by $\mathrm{MBE}$ headquarters. Our measure thus captures deviations from the standard rather than deviations from the norm, although, as will be shown in the section on establishing correlation, the standard and the norm are similar.

In determining whether a deviation has occurred, we utilize a cutoff point of one calendar year. We chose this mark because one year is a period long enough to determine the vector of actions chosen by the ML but not long enough to fully reveal the implication of the ML choices on the performance of the network in order to trigger corrective action.

The Standard Approach to Growing an MBE Network. Concerning how to develop an MBE network, MBE Headquarters provides recommendations to MLs on eight specific domains of activity, (1) marketing the MBE franchise, (2) selling the MBE franchise, (3) training the franchisees, (4) selecting sites, (5) designing and constructing MBE centers, (6) supporting the franchisee, (7) developing infrastructure, and (8) managing the franchisor/franchisee relationship. The eight domains can be considered "core" in the sense that nearly all potential elements of the system for network growth are interdependent with them (Hannan, Burton, \& Baron, 1996; Siggelkow, 2002) and they have a sizeable impact on the shape of future organizational elements (Baron, Hannan, \& Burton, 1999). 
The instructions for the first seven of these domains are organized in the form of a timeline known internally as the "52-week plan" that pertains to the initial year of the growth of a network. ${ }^{2}$ The 52-week plan lists 330-335 actions, the number of actions depending on whether the ML uses an area structure, to be taken by an ML, specifying their timing on a week by week basis. It is the number of specific actions in the 52-week plan followed by the ML that constitute the raw score mentioned in establishing departure from the standard approach.

It should be noted that the information contained in the 52-week plan, while codified, was still complex and somewhat ambiguous. The information represented a compilation of dozens of lessons learned through the building of the U.S. and other international networks. When specific problems were encountered, the solution to those problems was incorporated as a task in the 52week plan. For instance, experience revealed that it was desirable to delay some types of advertising until after the sixth week of network operation. Causal explanations of the mechanisms by which those moves affected growth were not, however, codified into the 52week plan. Furthermore, the implications of advertising from day one or delaying it by six weeks were addressed haphazardly, if at all. Such knowledge, instead of being codified, was transferred predominantly through personal communication between MLs. Furthermore, the interrelationship between various parts of the 52-week plan and the plan's applicability to different environments was unknown, even by headquarters. The 52-week plan represented codified local learning and no one had systematically mapped out the implications of altering or abandoning parts of that plan. While such learning was partially available in the larger MBE international network, again, it was only transferred unsystematically via personal communication between MLs.

\footnotetext{
${ }^{2}$ Our confidentiality agreement prevents us from revealing exact details of the 52-week plan.
} 
Instructions for the eighth domain, managing the franchisor/franchisee relationship, are, of necessity, less specific. These instructions are expected to align actions with the "core values" of MBE, which are sometimes referred to as the "family principle." ${ }^{3}$ The essence of the principle hinges on the fact that the franchise contract is a blunt governance tool that is inadequate to rectify minor infringements. Termination of the franchise contract, which contract is normally granted for a period of 10 years, is a costly and traumatic action that can be contemplated only in extreme situations. Thus, contracts are of limited value in restraining undesirable minor deviations in the behavior of the franchisee. Moreover, the threat of termination provides, at best, a weak lever to induce franchisees to undertake specific actions, such as marketing their services locally, investing in the remodeling of their store, or purchasing a new point of sale system. It certainly does not obligate them to provide positive referrals to prospective franchisees in order to help grow the network.

Since franchisees own their stores and their contracts cannot be terminated easily, the franchisor cannot control franchisees as if they were salaried company employees. Rather, the key task of the ML consists in empowering the franchisees so that they succeed in implementing the franchise; the success of the franchisee is a prerequisite for the success of the ML. It is for this reason that nurturing the franchisor/franchisee relationship means thinking of franchisees as if they were family members, such direct comparisons often being made in training meetings and materials, making persuasion the main means for effective governance. ${ }^{4}$

In order to determine the boundaries of the family principle, since its application is not as clearly codified as the 52-week plan, we interviewed a number of employees in the international

\footnotetext{
${ }^{3}$ See the Appendix B for further explanation.

4 The limitations of the contract as a governance tool and the fundamental importance of persuasion have been recognized as critical to franchise systems in general (Bradach, 1998; Seid \& Thomas, 2000).
} 
department at MBE headquarters and a sample of MBE MLs. ${ }^{5}$ Along with a more general discussion of the application of MBE's core values, we specifically asked three questions: (1) how would you deal with late royalty payments, (2) how have you dealt with late royalty payments while you were building your network, and (3) how do you get franchisees to make additional investments in their stores, such as remodeling, new equipment, etc. Using these answers, we developed a profile of how the family principle is used at MBE. For example, some ML actions correspond clearly to deviations from the standard way to manage the franchisor/franchisee relationship. Examples of such actions are frequent threats of termination, withholding support for minor reasons, and attempting to centralize activities that are normally considered to be responsibilities of the franchisees, such as marketing locally in their territory. Such actions conflict with the family principle, with the idea of working via persuasion rather than fiat. We compared the actions of MBE Israel's ML, as well as other MBE MLs, with the developed profile and computed a percentage of those who followed the family principle as outlined in the appendix to determine whether a significant deviation from this principle had occurred at MBE Israel.

Network Performance. Growth performance in early-stage franchise organizations is best reflected by the number of franchises sold and stores opened (Bradach, 1998; Love, 1986). Same store sales growth is generally not used as a measure of growth until the network reaches a stable size and growth in the number of stores abates. The growth in the number of franchises is a key measure of performance because it provides a vital revenue stream of franchise fee payments from the sale of new franchise units. That revenue, in turn, funds the development of the central infrastructure that is necessary to support the growing network of stores until royalty

\footnotetext{
5 The MLs interviewed in this regard include those from Poland, Mexico, Malaysia, Austria-Hungary, the Caribbean, the U.K., Portugal, Singapore, Philippines, Central America, Andean region, France, Canada, Japan,
} 
payments from those centers are sufficiently substantial (Bradach, 1998). Network growth is not only used by academics to measure early franchise performance, but is also one of the primary performance metrics both at MBE and in other franchising organizations (Bradach, 1998). Admittedly, using network growth as a performance metric may become problematic as a franchise organization matures (Bradach, 1998), ${ }^{6}$ but in this study Israel was newly opened and network growth is considered to be the most suitable measure. Growth was measured as the number of new franchises sold by the end of each calendar quarter and was determined using archival data.

\section{THE EFFECT OF PRESUMPTIVE ADAPTATION}

The MBE Israel experience falls into three distinct phases demarcated by decisions concerning presumptive adaptation. What follows is a description of those three phases and the results of the measurement of the presumptive adaptation and network growth variables.

\section{First Phase}

Albert Alhadef bought the rights to develop the MBE franchise network in Israel in August 1995. MBE, as they do with all MLs, began the process of replicating their successful network in Israel with a series of intensive training sessions spanning multiple weeks. During these training sessions, which included in-depth field experience, Albert was instructed in both building and operating a network and in establishing and operating a successful MBE store. MBE also aided Albert in the transfer of franchising knowledge by providing him with extensive manuals detailing the codified knowledge of both how to build and run a franchise network as well as an MBE store. Finally, to aid in implementing the system, MBE Headquarters ensured

Italy, and Turkey. 
that Albert was introduced to the global MBE network and given access to MLs in other countries who could serve as sources of advice and example. The goal of the training, the written materials, and the access to the network was transferring a proven system that had worked in many environments world wide.

With this wealth of available knowledge Albert opened the pilot store ${ }^{7}$ in July 1996, focusing on perfecting the sale of MBE services in Israel. From the beginning, Albert and the staff members that he hired believed that the basic MBE approach to both the business format and network growth had to be substantially adapted in order to be successful in Israel. Many of the business services being offered in the United States were not even defined or established in Israel. For example, the word "mailbox" had no meaning and the mailbox logo would mean little for attracting customers.

Albert was concerned that the fit of the MBE concept in Israel was not tight enough to attract sufficient numbers of franchisees to build a network. What initially attracted him to MBE, however, was the potential flexibility in the basic concept. He saw the flexibility in the business format as a tool to get MBE into the Israeli market.

The MBE concept is so flexible that I don't think MBE home office has all the solutions. There's no way they can see all the needs of all the world and what is needed because the mission of MBE is that we will personalize a convenient business solution. There is no way you can think about all the system, what [services] we should give where. - Albert

By picking and choosing among the various components of the MBE business format, Albert and his associates believed they could establish a profitable opportunity in Israel that would be easy for potential franchisees to see. However, such an approach required a period of

\footnotetext{
${ }^{6}$ When markets become saturated, franchise organizations often turn to increasing same store sales.

7 A pilot store is a model store, the first to be opened in a particular geographic area, which is run by the ML as a tangible example of how to operate a franchise unit.
} 
trial and error in the pilot store to determine what the right combination of services was for the Israeli market.

Accordingly, Albert's strategy was to perfect the pilot store before selling franchises thereby proving the viability of $\mathrm{MBE}$ in the Israeli market and enticing an otherwise skeptical population of potential franchisees to more easily buy into the MBE network. He believed that such a strategy would allow for even greater growth than the fastest growing MBE networks. Rather than expending significant amounts of time and money recruiting franchisees, as the plan calls for, Albert instead spent the majority of his effort the first two years attempting to perfect the pilot store. Of this time period his COO, Eitan, said, "We [were] doing in-store selling. We [were] staying behind the counter and selling stamps and making photocopies.”

\section{First Phase Results}

At the outset of the first phase, in an attempt to adapt to the perceived characteristics of the local environment marked by skepticism and suspicion of new franchising schemes, Albert abandoned the underlying logic of the 52-week plan and adapted the corporate knowledge on managing network growth to fit his own conception of key success factors. Of the 330 actions to be taken in the first year only 68 were followed (20.6\%), and the majority of these 68 were delayed by up to six months. In terms of the seven core domains embedded in the 52-week plan, only one that of infrastructure development concerned with the pilot store was addressed within the first two years of operation. The rest were intentionally neglected. Even by the most conservative estimates, this can clearly be considered a presumptive adaptation.

Not only was this deviation significant in comparison with headquarters' standard, which is to fulfill all 330 actions in their proper sequence within the first year of operation, but it is also significant in comparison with many of the other international networks, particularly those which 
were well established and growing quickly at the time MBE entered Israel. Table 1 below shows the number of steps followed by each of the 13 different international networks in existence prior to Israel (names are withheld for confidentiality reasons). While the number of steps Israel took can be accurately pinpointed due to our level of access to the data, only a range can be determined for the other networks. Data for the other networks was derived from interviews and archival data collected as part of a larger study. While the data did not allow for identification of the exact number of steps taken, the interviews elicited the general approach to conformity with the MBE system, which, in combination with archival data, was sufficient to compute the ranges included in Table $1 .^{8}$

Insert Table 1 About Here

According to MBE instructions and the experience of other international MLs, by the end of the first period, December 1997, Albert should have sold nearly 14 franchises and had over half that number of stores already in operation. Instead, he hadn't sold a single franchise and was still struggling to make the pilot store profitable. This was not as he had intended. Instead of a perfectly functioning, highly profitable pilot store that could attract potential franchisees, the pilot center wasn't even profitable and Albert had no network growth. ${ }^{9}$

${ }^{8}$ As one would expect in most settings not all networks follow the theorized pattern exactly. While there is not enough information on Country 3 in Table 1 to determine the cause of negative growth after year 4, the significant positive growth by year 4 for Country 7 and by year 6 for Country 10 both may be attributable to appropriate adaptations. Both networks, however, experienced slow initial growth as predicted. Moreover, the correlation between conformity to the system and growth through year 5 indicates that these two networks, especially Country 7 which experienced significant growth by year 4 , may be outliers rather than the norm.

${ }^{9}$ In fact, the pilot center did not become profitable until nearly half the final number of franchise units had been added to the network. Nor was the pilot center even verging on breakeven at the end of 1997. Sales revenue growth had stalled and did not increase until critical mass in the network as a whole had been achieved. 


\section{Second Phase}

In December 1997, Albert decided to send his COO, Eitan, to an MBE international conference in Milan, Italy. Italy was one of the more successful MBE international networks with nearly 200 stores established in a period of six years. At that conference, Eitan had an opportunity to see a successful network firsthand. He returned to Israel with a clearer picture of how the network was supposed to grow and the benefits of close adherence to the blueprint.

The trip to Italy was a milestone for me, I think for all of us. I think Albert will agree with this milestone... December '97. It seems like every franchisor must . . . get to the point where you say, 'Okay, let's start listening to others and what they are doing.' - Eitan

From December 1997, through the next two years, Albert and his top managers at headquarters, Eitan and Ari, shifted their policy from focusing on pilot store profitability to following the detailed blueprint that MBE had provided. During the initial period, when they had significantly adapted the system, they rarely asked for help with implementation problems. Having significantly adapted the system others could not help them much. As Ari commented, "We don't go back to the U.S. We have our own knowledge here," a sentiment that Albert echoed, "Ask the U.S. for help? It might be the proper way, but we have created our own experience."

In the second period, they copied the MBE system for network growth as closely as

possible and found that help in implementing the system was readily available.

We used the same process exactly and it went well. [We copied] even the small issues like how much details you give over the phone, how much details you give in a meeting, what type of questions people ask you and what type of answers you give, and what you don't answer then but leave to a later stage. - Albert

During the preparation to implement. Albert and his management team had contact with successful MLs, such as the Italian ML, and significant iterative contact with MBE headquarters 
in the U.S. For instance, while the basic implementation steps came from Italy they were in frequent contact with MBE headquarters concerning materials to use and clarification of system details. Albert commented that "some clarifications we had to ask. For these types of questions we went to the U.S. [The director of the international department] helped us with some fine tuning."

\section{Second Phase Results}

The first phase was followed, in December 1997, with a decision to backtrack and reapproach the growth of the network by implementing the MBE system in the recommended way, following the steps outlined in the 52-week plan. Within the first year of the second phase the remaining 262 steps were followed. Thus, this phase is marked by a reversal of the previous presumptive adaptation. Instead of following his own course, Albert implemented the original practice as closely as possible.

During the second phase, with growth beginning almost immediately, the Israeli network grew from only one pilot store to two pilot stores plus 15 franchise outlets in two years. Israel was among the fastest growing young MBE networks at the time. ${ }^{10}$ At first glance, it might seem obvious that focusing on selling franchises would increase the size of the network. While this was the direct result of Albert's shift from presumptive adaptation to closer adherence to the original practice, it was not a shift in Albert's original intention. His intention from the beginning was to build a fast-growing network. The shift, then, wasn't from a focus on growing the network, but from attempting to adapt the system for growing the network to fit local

\footnotetext{
${ }^{10}$ Growth often accelerates with age, but compared with other fairly new franchise networks they were now the second fastest growing network in MBE history.
} 
conditions in order to achieve better-than-typical MBE growth rate. As he began to follow the pattern recommended by $\mathrm{MBE}$, Albert was finally meeting the original growth predictions he and MBE headquarters had established when he first bought the rights to build the MBE network in Israel.

\section{Third Phase}

As the network grew, Albert began to have minor problems with late royalty payments. The Israeli society is one characterized by a fear of ambiguous situations (such as the potential success of an untried franchise format), ${ }^{11}$ a strong sense of the cost of time and money, and a moderately strong sense of individuality ${ }^{12}$ coupled with a noted reluctance to accept and comply with developing social norms or the expectations of others (Mann, 1977). This environmental characteristic is most easily seen in the characterization of Israeli markets as requiring quick validation in a fast-paced do-or-die atmosphere. As a consequence, new franchisees are under tremendous pressure to become successful quickly.

The result of this cultural tendency in the MBE Israel network was for the franchisees to temporarily withhold royalty payments in order to use those funds as an interest-free, short-term loan to expand their stores as quickly as possible. The norm of on-time royalty payments, typical in other MBE networks, was disregarded by some franchisees who were trying to swiftly recoup their investments by capitalizing on individual growth prospects. Albert's approach to this problem entailed persuasion, cajoling, negotiation, and individualized attention to the needs of each franchisee.

\footnotetext{
11 Israel ranks $19^{\text {th }}$ on Hofstede's (1997) cultural indices for uncertainty avoidance with a score of 82 as compared to a U.S. score of 46 and an average across all 53 countries in his sample of 65 .

12 Israel ranks $19^{\text {th }}$ on Hofstede's (1997) cultural indices for individualism with a score of 54 as compared to a U.S. score of 91 and an average across all 53 countries in his sample of 43.
} 
In the latter half of 1999, Albert decided to shift his focus to a new business. For a number of months prior to December 1999, he slowly turned over operation of the business to Eitan, his COO, promoting him to CEO in December of that year. Eitan had initiated the shift toward following the pattern for network growth outlined in the 52-week plan and was instrumental in implementing that plan. While Eitan had primarily been involved in selling new franchises, as Albert withdrew Eitan became more involved with existing franchisees. Eitan felt that the Israeli franchisees were different from those in other locales and would not respond sufficiently to persuasion. As a result, when he became CEO he consistently confronted the franchisees, even to the point of occasionally threatening a withdrawal of support from headquarters if royalty payments were not on time. Ultimately, Eitan was successful in resolving the problems with late royalty payments. As Albert said, "He was tough on it. He was tough on collecting the money."

However, Eitan's approach to resolving the problem had resulted in significant mistrust from the existing franchisees. Their general opinion was that Eitan was not the right person to run the network. The strain resulted in open disputes between MBE Israel top management and the franchisees, many of whom were sufficiently unhappy that they advised prospective franchisees against joining the network. Existing leads soon chose not to enter the network and the sale of new franchises halted.

In an effort to overcome the negative feelings between himself and the franchisees, Eitan completely shifted his attention from selling new franchises to supporting existing franchisees with the intent to increase individual store sales revenues. If existing store sales increased quickly enough, franchisees might begin to give positive referrals again to prospective franchisees, restarting growth. In order to maximize this support effort and hopefully overcome 
resentment quickly, Eitan hired new personnel for headquarters including marketing and operations directors.

Part of Eitan's efforts at franchisee support included involvement in day-to-day franchise operations. For instance, in an attempt to increase turnover at the unit level as well as ensure ontime royalty payments, he attempted to centralize some operations by generating business through a centralized internet interface and then passing the business along to the franchisees. Despite, or possibly because of, Eitan's efforts at supporting franchisees their mistrust only deepened. Albert comments, “[He] was supporting them too much. You cannot help someone else's business by controlling it." By the end of 2000, the situation had deteriorated to the point that Eitan was forced to leave the company, and Albert brought in another CEO.

\section{Phase Three Results}

The third phase is marked by presumptive adaptation in terms of significant alterations to MBE's family principle and basic franchising principles such as decentralization of operations. Typically, franchise firms are decentralized operations with the franchisor spending a large proportion of his/her time managing the relationship with the franchisees (Bradach, 1998; Kaufmann \& Eroglu, 1998). Decentralization is requisite as franchisees are owners as well as managers. Managing the relationship between the franchisor and the franchisees is important because, barring gross negligence, the franchisor has little ultimate authority over the franchisees and has to rely on relationships in order to ensure their cooperation in aspects of the business requiring coordination between franchisor and franchisee. Managing the relationship appropriately is also vital to the growth of the network because good relationships reflect in positive referrals to prospective franchisees. 
While Albert had always maintained a decentralized structure and been very careful in his approach to his franchisees even when there were difficulties in the relationship, Eitan did things differently. First, by centralizing some aspects of the business Eitan altered basic franchising principles by changing parts of the franchisor/franchisee relationship into an employer/employee relationship. Second, his confrontational approach to franchisee difficulties was an abrogation of the family principle that was explicitly counter to headquarters' recommendations and to the approach of $93 \%$ of all MLs prior to Israel, and $84 \%$ of those who began operations after Israel did, who followed the family principle as recommended by MBE headquarters extremely closely.

With only one exception, prior to Israel all the MLs used a very accommodating, persuasive interaction style coupled with extended patience and forbearance for late or nonroyalty payments and a clear respect for the franchisee as the primary interface with the customer. For instance, nearly all of the MLs approached the issue of late royalty payments with a lengthy process spanning six months or more that began with personal phone calls and friendly letters of reminder. For franchisees that could not pay due to financial difficulties (which is often interpreted broadly to include difficulties breaking even), forbearance was indefinite and involved substantial support in helping the franchisees become profitable. This was especially true for small networks, where failure rates and negative referrals can be especially damaging. The following comment from the Austrian ML, concerning a franchisee that had not paid royalties in over a year, illustrates this approach and its importance for small networks: "At the stage we are in of our development it is very difficult to take such a decision [terminating a franchisee]. There is the hope that gradually you will receive some part of it if not all. You tend to take the somewhat softer approach which we are doing." 
The result of Eitan's presumptive adaptation was zero network growth during his tenure as CEO. Moreover, in his attempt to support the existing franchisees, Eitan deviated from the system for network growth as well in terms of hiring additional personnel such as a marketing and operations manager. The system for network growth, as outlined in the manuals given to MLs, prescribed delaying the hire of additional headquarters employees until the network was much larger in size. Eitan discovered why as existing monthly royalty payments, while on time now, were insufficient by themselves to fund the extra headquarters employees. With the lack of fees from new franchise sales, his approach quickly became financially unsustainable.

\section{Establishing Correlation}

The following figure shows the growth pattern of the MBE Israel network along with the points demarcating the different phases where decisions concerning presumptive adaptation were made.

Insert Figure 1 about here

There is a clear pattern concerning presumptive adaptation beginning, with a decision to presumptively adapt the system, followed by implementing a close copy, and ending with another decision to presumptively adapt. The dependent variable, network growth, also followed a clear pattern. While a pilot store was operated by the ML between 1995 and 1997, no franchise units were sold during that time. This period was followed by fast growth as 15 franchise units were sold between 1998 and 1999. In 2000, however, the growth stalled again, with no new stores sold between 2000 and the end of the period of observation in July 2001.

Overlaying the two patterns produces the following:

Insert Table 2 about here 


\section{Establishing Causality}

In retrospect, the MBE Israel saga could be analyzed as a naturally occurring, repeatedtreatment quasi-experiment. ${ }^{13}$ The presence of a naturally occurring, repeated-treatment quasiexperiment suggests a causal relationship between presumptive adaptation and network growth. In this study, we follow Cook and Campbell's (1979) approach to quasi-experiments.

Specifically, a quasi-experimental design is aptly suited for studies where the researcher does not have control over the incidence of the treatment, and hence cannot control randomization, but has rich access to data and exact knowledge of when the treatment is implemented (Cook 1991). Quasi-experiments, as in true experiments, allow one to make causal inferences, if, as in this study, there is temporal precedence, correlation between independent and dependent variables, and evidence or logic allowing one to address the counterfactual, or what might have occurred if the treatment were not given (Shadish, Cook, \& Campbell, 2002).

The quasi-experimental design that occurred in this study is a repeated-treatment design. In this design, the treatment is applied, removed, and applied again within the same population. It is justified when the investigator has access to only one population and the program is introduced to the entire population (Cook, Campbell, \& Peracchio, 1990). The repeated treatment design is frequently used by researchers in other disciplines, such as psychology (e.g., Barlow \& Hersen, 1984), and is considered to be strong, due to the repeated nature of the design, in terms of accounting for threats to the validity of the causal inferences (Shadish et al., 2002;

Cook \& Campbell, 1979). As with any quasi-experimental study, or any study where causality is

\footnotetext{
${ }^{13}$ While we have portrayed the experiment as a set of three phases, indicating an $\mathrm{N}$ of three, the data actually comprises a set of 23 quarters from September 1995 to July 2001 with the treatment being applied for the first eight and last six of the quarters and removed during the middle nine. This extends the observations over time
} 
inferred for that matter, careful consideration must be given to alternative explanations.

Generally, this design is strongest when treatments are unobtrusive and are not confounded by temporal cycles (Shadish et al., 2002). The retrospective nature of this study ensures that it is unobtrusive. The issue of temporal cycles along with additional traditional and logical threats to validity will be discussed in the next section.

The design is depicted below; its most interpretable outcome is when the first observation $\left(\mathrm{O}_{1}\right)$ differs from the second $\left(\mathrm{O}_{2}\right)$, the third $\left(\mathrm{O}_{3}\right)$ differs from the fourth $\left(\mathrm{O}_{4}\right)$, and the $\mathrm{O}_{3}-\mathrm{O}_{4}$ difference is in the same direction as the $\mathrm{O}_{1}-\mathrm{O}_{2}$ difference. $\mathrm{X}$ indicates application of the treatment while /X indicates its removal.

\section{$\mathrm{O}_{1} \mathrm{X} \mathrm{O}_{2} / \mathrm{X} \mathrm{O}_{3} \mathrm{X}_{4}$}

The treatment in our study occurs when the ML in Israel decides to presumptively adapt the MBE system for network growth. If the treatment has an effect on network growth, we will expect that growth will be stagnant after each decision to significantly adapt the system and that growth will accelerate following a decision to implement the standardized system. That is, that $\mathrm{O}_{1}$ (the initial growth forecast developed by Albert and MBE headquarters in San Diego) will be higher than $\mathrm{O}_{2}$ (the observation after the decision to adapt), $\mathrm{O}_{3}$ (following the decision to implement the standardized system) will be higher than $\mathrm{O}_{2}$, and the growth rate of $\mathrm{O}_{4}$ (following the decision to adapt again) will be lower than $\mathrm{O}_{3}$. This is exactly what we find and what figure 1 (reported earlier) illustrates.

(King, Keohane, \& Verba, 1994), increasing the statistical validity of the analysis (Shadish et al., 2002) and, as we pursue below, allowing us to rule out the possibility that the pattern occurs randomly. 


\section{Threats to Validity}

Since the treatment is not applied randomly, inferring causality in a quasi-experimental setting necessitates a special effort to carefully weigh alternative explanations of the observed results. This task is particularly important in our setting because the treatment is endogenous, meaning that additional, possibly neglected, confounding factors may be correlated with the treatment.

However, while not completely resolving the issue, one of the strengths of a repeatedtreatment, quasi-experimental design is that potential threats to the validity of the entire pattern have to follow the same on-off-on pattern as the treatment (the decision to presumptively adapt) (Cook \& Campbell, 1979). While we cannot completely rule out the possibility that such events occurred, we are not aware of any event other than the treatment that followed this pattern fully. There were other factors, such as changes in the business climate that conceivably could have affected network growth across the entire period. However, upon scrutiny we find that these factors remained constant across all three time periods or across at least two of the three time periods. There may also, however, be alternative explanations to the measured results for single periods; such factors are also explored below, as explanations for each single period of the study may conceivably ultimately account for the entire pattern.

Concerning the economic climate of Israel, we measured both quarterly economic indicators and average store revenue in the MBE Israel network to determine if a slowdown in economic growth was responsible for the decline in sales of new franchises during the last part of the period of observation. GDP increased during the entire period of the study but at a slightly decreasing rate during the last two years of the study. We constructed a measure of elasticity 
between the economic indicators and store revenue. The elasticity ${ }^{14}$ during the entire period is very small (ranging from -.025 to .317) and is random, with no clear pattern emerging. For the economic climate to have been the cause of the growth changes in climate should coincide to some degree with the pattern of network growth results. At the very least, elasticity should be negative and high or becoming significantly higher during the first and third periods. However, this is not the case.

Despite the overall economic climate, it is possible that lack of franchisee profitability (a possible motive for giving negative referrals to potential franchisees), rather than Eitan's policy changes, led to the decline in performance in the third period. However, for this to be the case one would expect either a precipitous decline in store revenues (data on store profitability is not available) at the time of Eitan's promotion (December 1999) or a perennial lack of profitability with little hope for future prospects. This, however, was not the case. Accounting for month-tomonth variation in same-store sales, every single MBE Israel franchise saw steady increases in store revenue from inception through the end of 1999 , with $86 \%$ seeing a steady increase through the end of 2000.

Calculating a six-month average for all stores in operation at least two months (to allow for minimal learning curve effects), the average revenue for the first six months of 1999 was $14.5 \%$ higher than the last six months of 1998. The average from July to December 1999 was another $8.0 \%$ higher than the first six months of 1999 for a year to year increase of $23.7 \%$. The first six months of 2000 registered a $12 \%$ decrease, although all except two increased in revenue. Moreover, by the end of 2000, revenues had rebounded to only a $1 \%$ decrease over year-end 1999 figures, with all stores except two increasing same store revenues over that period. Even

\footnotetext{
${ }^{14}$ Elasticities are computed as they test not only correlation but the sensitivity of franchisee performance to even small changes in GDP.
} 
when decreasing the sample by increasing the required number of months in operation to three to allow for a longer learning curve, the year-to-year increase, 1998 to 1999 , is $21.6 \%{ }^{15}$ Despite the mixed same store sales growth in 2000 , lack of revenue does not seem to be the cause of the negative performance observed in the third period. For lack of revenue to be the cause of the observed pattern, one would expect chronic low revenue or decreasing revenue for the period prior to Eitan's promotion. Otherwise, while in actuality there were no franchise sales following Eitan's promotion, one would expect to see sales in at least the first six months of his tenure as CEO. While it is possible that no new stores were scheduled to be added at that point, and declining revenue during the first six months of 2000 (even though only a few stores were declining) inhibited new franchisees from joining the network one would expect to see the situation eased as revenues rebounded in the second half of 2000. Such was not the case.

A second possible threat is that the observed pattern occurred by luck alone. Across the three phases there are a total of eight possible outcomes, ranging from three consecutive failures to three consecutive successes and all permutations in between; if the pattern occurred by luck alone, one would expect to find an outcome of failure, success, failure only $12.5 \%$ of the time (each success or failure having a probability of .5). However, we can further divide the three phases into a set of eight, nine, and six successive quarters. If the growth is random, one would expect it to be random in each time period. However, in the first phase we have eight consecutive no-growth quarters, which, if growth were random, would occur with a probability of .0004. Six of the nine quarters in the second phase show growth, although only three are consecutive, which would occur randomly less than half the time. Finally, all six of the

\footnotetext{
${ }^{15}$ Since the same store revenue was generally increasing for all stores during this period, extending the cutoff date for including stores in the sample will naturally decrease the year to year percentage increase. However, even increasing the cutoff to 6 months to allow for a longer learning curve yields a $12.5 \%$ year to year increase in sales at the time Eitan became CEO.
} 
consecutive quarters in the third phase have zero growth, for a probability of .016 . Even if one were to assume that the second phase was completely random, the overall probability of observing the entire pattern if it were random is less than $1 / 1000^{\text {th }}$ of a percentage point. Thus, it seems unlikely that the observed pattern is not due solely to luck.

Another possible threat is that the individuals at MBE Israel learned from the application of the treatment the first time and specifically avoided those problems the second time around. While top management did realize that a lack of growth at the beginning was directly due to not "listening to others" and subsequently copied the MBE system for network growth as closely as possible, they did not connect network growth with the concept of following the system as a whole. Instead they saw it as adherence to a particular part of that system, specifically the timing of selling franchises, vis a vis the operation of the pilot store. This is clearly seen by the departure from that same system during the last two years of the period of observation. At the time, no one, including the observers, realized that the treatment being applied was a departure from the system as a whole. The fact that the essence of the treatment was recognized retrospectively only enhances the validity of the study. ${ }^{16}$

A fourth alternative explanation for the positive growth in the middle of the period of observation is that Albert was correct that by perfecting the pilot store before selling franchises resulted in excellent growth. This, however, was not the case, because the pilot stores were never able to break even until after there were sufficient numbers in the network to bring up the

\footnotetext{
${ }^{16}$ Campbell \& Overman (1988) reach a similar conclusion about the likelihood of social threats to validity in their study of the Connecticut crackdown on speeding.
} 
average revenue of all the stores in the network. Beyond that, such a scenario would not explain the zero growth observed at the end of the period.

Another potential explanation for the positive growth could be a lag between demonstration of the MBE business and actual franchisee recruitment. A time lag, however, of nearly two years between demonstration of the concept and sale of the franchise would be required if this were the cause of the pattern found in the data. Moreover, the data indicate that the average time from demonstration to franchise sale was less than four months during the period in question.

A sixth potential threat is that factors correlated with Eitan's promotion to CEO were responsible for the zero growth following that action. Such factors could be an increase in pressure for financial performance due to Albert's shift to a passive investor or possibly changes in Eitan's compensation package. Such factors, however, while being an alternative or complementary explanation for the decision to confront the franchisees concerning late royalty payments and for the decision to institute centralized operations do not alter the conclusion that Eitan's policy changes did in fact conflict with the family principle. Nor do such factors address the negative reaction of the franchisees, which, according to all accounts, was in direct response to changes initiated by Eitan.

A final threat to validity is that turnover in the MBE network caused either the pattern of growth or the pattern of decline in the third period. This could occur either through widespread turnover in headquarters or, a large-scale change in the way the business was operated outside of the changes detailed in the case. Through the period of observation, however, there were only incidental personnel changes at headquarters and, outside of the adherence to the 52-week plan, intentional changes in the franchisor/franchisee relationship, and Eitan's attempt at 
centralization, there were no major changes in the way the business was operated. Eitan's promotion to $\mathrm{CEO}$ was a major determinant in the second decision to deviate from the system for network growth. His promotion, however, did not result in a major change in other operating policies. Albert had been slowly removing himself from daily operations for some time before the promotion, leaving Eitan in charge of the day-to-day decisions and the actual operation of the network. The key change in Eitan's promotion was that Eitan, rather than Albert, became the primary ML interface with the franchisee. The centralization of operations is obviously a major operating change. However, both pilot center and franchisee revenues grew during this period. Moreover, while it was a radical change for the operation of the stores, this paper is about adaptations of the system for network growth, and the primary change in this policy in that regard was intrusion in the operation of stores and attempting to manage franchisees by fiat.

Finally, we recognize that there may be instability in the measures or other unmeasured factors that might account for the results. While this is the case with most studies, this threat is typically heightened in a naturally occurring quasi-experiment due to the often endogenous nature of policy changes. However, while the possibility of significant, omitted variables may be higher, the repeated-treatment design substantially mitigates this threat. Moreover, data were gathered in real-time, as the events unfolded, over a seven-year period. During and beyond that entire period we had full access to the major parties, allowing us to follow closely the development of the MBE Israel network. During the period of observation and during interviews with all the principal players, no factors other than those discussed here emerged as either major policy changes or external factors that may have caused the observed pattern. Other than the treatment, we know of no factors which were applied, removed, and reapplied and are unaware 
of any major omitted variables which might possibly account for shifts in performance in any given time period.

\section{DISCUSSION AND CONCLUSION}

Developing counterexamples is a standard part of creative research to determine the limitations of a proposed approach. An example of an approach that did not work as desired may point to serious shortcomings in the current system of beliefs, unless it is a bizarre case that is relatively rare and can safely be ignored. However, if the example points to a failure that could affect an important segment of the relevant population, a change in existing policy may be required. Presumably these investigations will lead to changes in policy or procedures to reduce the chances of recurrence (Hoaglin, Light, McPeek, Mosteller, \& Stoto, 1982).

We believe that MBE Israel is a representative counterexample to conventional wisdom concerning presumptive adaptation. The example is representative to the extent that the setting is similar to that faced by other franchisees and to the extent to which franchisees and others engaged in transfers of complex knowledge ascribe the same meaning to the adaptation decision as Albert did (Ilgen, 1986). In other words, generalizability of the MBE Israel example would be compromised if the setting of Israel is an outlier.

Evidence from within the international MBE community, other franchising contexts, and the transfer of organizational practices outside of franchising indicates that the results obtained by Albert are not atypical. For instance, the correlation between the number of steps in the 52week plan followed and the number of franchisees added each year for the entire MBE international network begins at .86 (statistically significant at the .05 level) in the second year of ML operation and decreases slowly to .51 by the eighth year, remaining statistically significant through the fifth year of operation. The correlation was computed using the most conservative 
estimate (least number of steps followed for high conformers and most for low conformers) and suggests that our findings for MBE Israel are consistent with the experience of the larger MBE international network.

Moreover, through interviews conducted as part of a larger study involving knowledge transfer within the international MBE network, we found that nearly all of the MBE MLs have faced the issue of presumptive adaptation with varying decisions and varying results. Some $\mathrm{MLs}^{17}$ utilized an approach similar to Albert's and presumptively adapted the MBE system for network growth, with the same tendency towards low growth results.

Other MLs adapted presumptively but to a lesser degree (neglecting some, albeit fewer, steps in the 52-week plan) and found that adaptation created difficulties that slowed and even reversed growth. For example, one particular ML devoted significant up-front time altering lead generation materials to "ensure" a greater fit with local culture with the intent to thereby increase the rate of network growth. While such a move may have been warranted, the focus on changing the materials required significant time and money that needed to be spent on other aspects of network growth, impairing the MLs ability to support existing franchisees and eventually resulting in a revenue shortfall. The revenue shortfall led to a vicious cycle where lack of resources to spend on lead generation slowed down network growth, which in turn curtailed support and revenue growth. Ultimately the ML ended the affiliation with MBE due to financial duress. This example highlights the causally ambiguous nature of the template with its subsequent ambiguous interdependencies and suggests that even relatively moderate presumptive adaptations may also harm network performance.

\footnotetext{
${ }^{17}$ Names withheld for confidentiality reasons.
} 
Other MLs chose to follow the MBE system as closely as possible, with results opposite to Albert's initial results. For instance, the Italian ML commented, "Our system is very close to the U.S. . . There was no point in buying a concept and then doing something else. . . We do it exactly like the U.S., not only in image but in business."

Yet other MLs realized the need to adapt, but chose to begin that adaptation from a faithful replica of the original practice, and then incrementally adapting only after the practice was sufficiently understood in the local context (not until significant time had passed). The Canadian ML, for instance, faithfully followed the U.S. model for both network growth and the business format for the first three to four years of operation. At that point, he began to slowly adapt the business format by incrementally emphasizing the sale of document services over shipping. To support this shift in the business format, he gradually shifted the lead generation process (a focus on document services requires a more technologically sophisticated franchisee) as well as the substance of the training franchisees received.

"I said 'hey, this [the original MBE model] is a pretty successful concept,' and I still believe it is probably one of the most successful, if not the most successful, service concepts in the world. . . . So, [concerning modifications] I went kind of slow to start with.” - Canadian $M L$

As reported in Table 1 previously, the results of these MLs are in stark contrast to those of Albert and others who engaged in presumptive adaptation.

Our conclusions could be generalized beyond MBE to the extent to which the lessons are transferable to other settings (Denzin \& Lincoln, 1998). In the domain of franchising, such lessons seem especially applicable to organizations relying on a ML system. More generally, however, the MBE Israel example speaks to the broader phenomenon of adaptation in the transfer of franchising knowledge to franchisees at all levels. For instance, the proclivity for presumptive adaptation seems to be characteristic of franchising in general, not just MBE, and 
not just of the method for franchising growth. Franchisees often attempt to improve on the franchise system that they join by immediately introducing major modifications because they believe that they can quickly improve its profitability in their unique situation (Kaufmann \& Eroglu, 1998; Seid \& Thomas, 2000).

Not only does this seem to be a decision commonly approached, but the pattern of results obtained at MBE Israel also seems to be characteristic of other franchisees. Franchisees in general are explicitly warned to refrain from significant adaptation by franchisors as well as by franchising experts, and many franchisees have learned the same lesson that Albert did (Bradach, 1998; Seid \& Thomas, 2000). Some franchisors, recognizing this pattern, have enacted policies to overcome it. For example, Great Harvest Bread Co. requires that its franchisees adhere closely to the original practice, allowing incremental modifications only after at least a year has passed (Great Harvest Bread, 1999).

While, to some extent, franchising may be a specialized setting because the locus of adaptation often lies with the recipient rather than headquarters, policies acknowledging the potential difficulties in presumptive adaptation occur in contexts other than franchising. Knowledge transfer policies at Xerox Europe and Intel are illustrative of the potential generalizability outside of the franchising domain. Xerox Europe, which has a long and distinguished history transferring best practices, demands that receiving units copy the practice exactly as it is performed at the source until it is able to achieve similar results (Financial Times, 1997). Intel also utilizes this "copy exact" policy when establishing new semi-conductor fabs, requiring engineers to replicate fab designs and work practices with exactitude (McDonald, 1998). In other words, both organizations strongly discourage presumptive adaptation. 
The MBE Israel case thus suggests that the seemingly sensible idea of presumptively adapting a practice to fit a particular environment, to be responsive to local institutions, or to attempt to anticipate local isomorphic pressures may be counterproductive when transferring an insufficiently understood practice across borders. This finding, at the very least, suggests that presumptive adaptation is an important managerial choice that has thus far received little consideration. The decision to presumptively adapt is different from the decision to initiate the transfer and deserves consideration in its own right. This finding is also a note of caution against engaging in extensive presumptive adaptation.

An important question, then, is how different from the original practice can an adaptation effort be before the diagnostic value of the original template is effectively lost, i.e., before it becomes comparatively more efficient to resort to trial and error than to continue to use the original for diagnosis. For moderately complex practices, however, even a small departure from the original may create major problems. This sensitivity to the adaptation is compounded by the fact that the host environment is often not well understood, even by the receiving unit. Nor, given the fact that the practice is new to the receiving unit, is the interaction between the adapted practice and systemic effects likely to be completely understood (Ghoshal \& Westney, 1993). Thus, presuming that adaptation can be planned and implemented in advance entails presuming extraordinary understanding and foresight not just for the recipient (the usual subject) but the source as well. Yet, long term use of an identical replica of the original practice may turn out to be unrealistic. Indeed, some obvious features may even have to be modified from the start.

MBE Israel's experience suggests that the fact that a practice will eventually be adapted to fit the local environment does not necessarily mean that presumptive adaptation is necessary, i.e., that the form of departure, or implemented form of the practice, be a significantly modified 
one. In this sense, the MBE case serves as a striking counterexample to such an assumption.

Beginning the transfer process by introducing modifications to a working practice before implementing it in another location, or beginning the adaptation process with a large change from the original, could have deleterious consequences.

This suggests some additional hypotheses for further research. First, the presumption that a practice can be implemented without using the original as a referent is likely to lead to a form of departure, or degree of adaptation, that is significantly different form the original practice. Second, the reverse is also likely true, a healthy regard for the difficulty of transferring practices and the value of the original as a diagnostic tool is likely to lead to implementing a close replica of the original. Finally, given MBE Israel's experience, a more general hypothesis would be that presumptive adaptation is likely to lead to transfer failure, while copying the original as closely as possibly is likely to lead to transfer success. Counter intuitively, arriving at a final fit with a local environment may be greatly facilitated by beginning with a replica that helps preserve, as much as possible, the diagnostic value of the working example rather than one aimed at creating fit as quickly as possible.

Table 1: Steps Followed in 52-Week Plan and Network Growth

\begin{tabular}{|c|l|l|c|c|c|c|}
\hline Country & $\begin{array}{l}\text { Min. \# of } \\
\text { steps in 52- } \\
\text { week plan } \\
\text { followed }\end{array}$ & $\begin{array}{l}\text { Max. \# of } \\
\text { steps in 52- } \\
\text { week plan } \\
\text { followed * }\end{array}$ & $\begin{array}{l}\text { Cumulative } \\
\text { \# franchises } \\
\text { sold after 2 } \\
\text { years }\end{array}$ & $\begin{array}{l}\text { Cumulative } \\
\text { \# franchises } \\
\text { sold after 4 } \\
\text { years }\end{array}$ & $\begin{array}{l}\text { Cumulative } \\
\text { \# franchises } \\
\text { sold after 6 } \\
\text { years** }\end{array}$ & $\begin{array}{l}\text { Cumulative } \\
\text { \# franchises } \\
\text { sold after 8 } \\
\text { years** }\end{array}$ \\
\hline 1 & 259 & 335 & 19 & 23 & 96 & 168 \\
\hline 2 & 259 & 335 & 14 & 62 & 53 & 53 \\
\hline 3 & 238 & 316 & 22 & 31 & 28 & 20 \\
\hline 4 & 196 & 244 & 11 & 93 & 169 & 325 \\
\hline 5 & 131 & 210 & 3 & 8 & 16 & 25 \\
\hline 6 & 131 & 210 & 6 & 29 & 27 & 13 \\
\hline 7 & 68 & 103 & 5 & 20 & 34 & 43 \\
\hline 8 & 68 & 103 & 3 & 10 & 15 & 13 \\
\hline 9 & 68 & 103 & 2 & 11 & 11 & 5 \\
\hline
\end{tabular}




\begin{tabular}{|c|c|c|c|c|c|c|}
\hline 10 & 68 & 103 & 4 & 13 & 25 & 37 \\
\hline 11 & 68 & 103 & 3 & 7 & 5 & 5 \\
\hline 12 & 68 & 103 & 1 & 5 & 11 & 14 \\
\hline 13 & 68 & 103 & 2 & 6 & 5 & 9 \\
\hline Israel & 68 & 68 & 0 & 6 & 12 & 12 \\
\hline
\end{tabular}

* Out of 330/335 possible steps (5 of the steps are only for those with an area franchisee structure).

** Cumulative number also includes stores closed.

Table 2: Correlation between Presumptive Adaptation and Network Growth

\begin{tabular}{|c|c|c|c|}
\hline & $\mathbf{1 9 9 5 - 1 9 9 7}$ & $\mathbf{1 9 9 8 - 1 9 9 9}$ & $\mathbf{2 0 0 0 - 2 0 0 1}$ \\
\hline $\begin{array}{c}\text { Degree of } \\
\text { Adaptation }\end{array}$ & $\begin{array}{c}\text { Presumptive } \\
\text { Adaptation }\end{array}$ & $\begin{array}{c}\text { System Copied } \\
\text { Closely }\end{array}$ & $\begin{array}{c}\text { Presumptive } \\
\text { Adaptation }\end{array}$ \\
\hline $\begin{array}{c}\text { \# New Franchises } \\
\text { Sold }\end{array}$ & $\begin{array}{c}0 \\
\text { (2 pilot stores in } \\
\text { operation by ML) }\end{array}$ & 15 & 0 \\
\hline
\end{tabular}


Figure 1

\section{Growth of the MBE Israel Network}

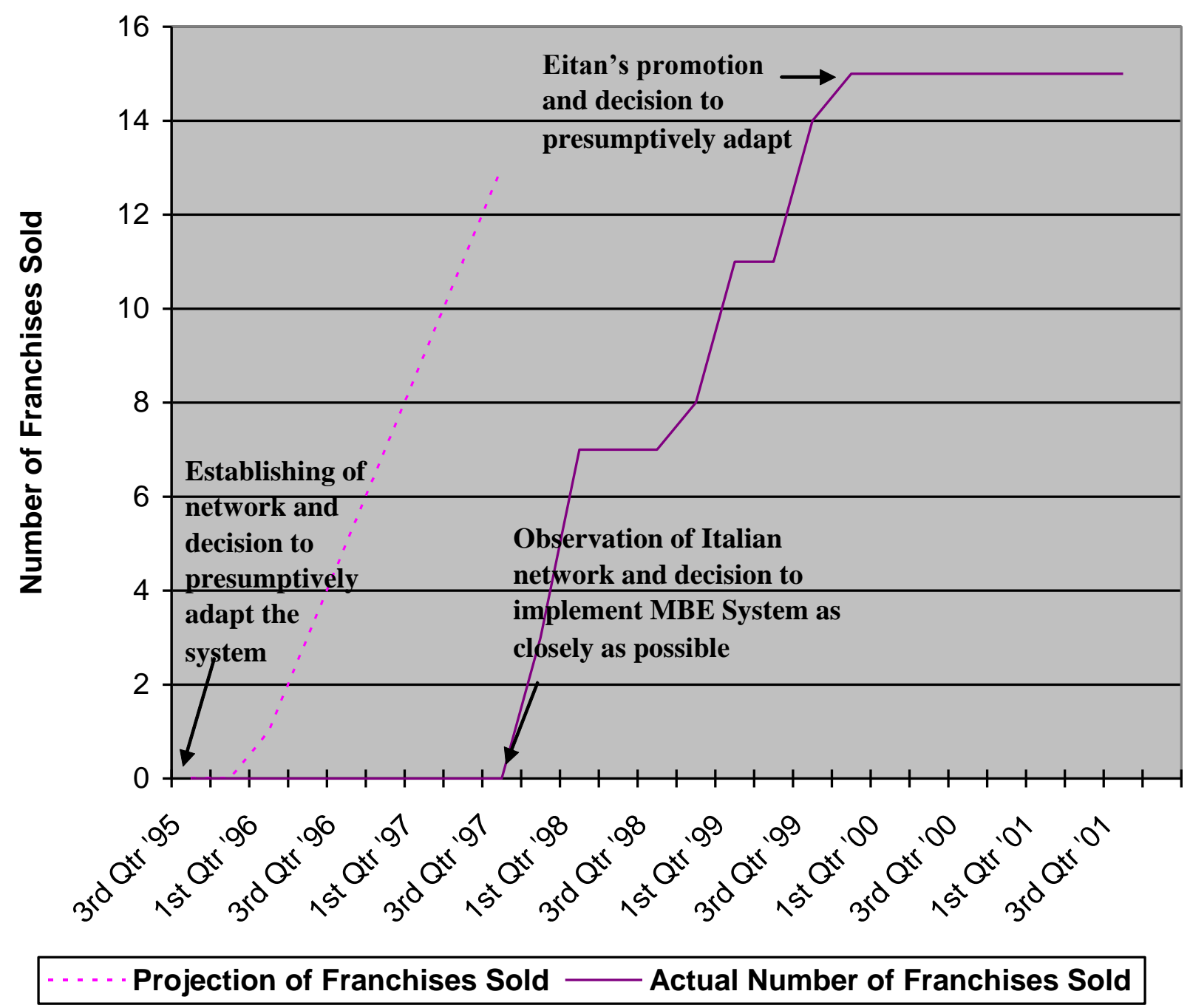




\section{REFERENCES}

Baron, J. N., Hannan, M. T., \& Burton, M. D. 1999. Building the Iron Cage: Determinants of Managerial Intensity in the Early Years of Organizations. American Sociological Review, 64: 527-547.

Barlow, D.H., \& Hersen, M. 1984. Single Case Experimental Designs: Strategies for Studying Behavior Change ( $2^{\text {nd }}$ ed.). New York: Pergamon Press.

Bartlett, C. A., \& Ghoshal, S. 1989. Managing across Borders: The Transnational Solution. Boston: Harvard Business School Press.

Bradach, J. L. 1998. Franchise Organizations. Boston: Harvard Business School Press.

Brannen Y, Wilson JM. 1996, April 26. What Does Mickey Mouse Mean to You?, Financial Times: 14-16.

Burgelman, R. A. 1983. A Process Model of Internal Corporate Venturing in the Diversified Major Firm. Administrative Science Quarterly, 28: 223-244.

Campbell, D. T., \& Overman, E. S. 1988. Methodology and Epistemology for Social Science : Selected Papers. Chicago: University of Chicago Press.

Cook, T. D. 1991. Clarifying the Warrant for Generalized Causal Inferences in QuasiExperimentation. In M. W. McLaughlin, \& D. C. Phillips (Eds.), Evaluation and Education: At Quarter Century: Ninetieth Yearbook of the National Society for the Study of Education: 115-145. Chicago, IL: University of Chicago Press.

Cook, T. D., \& Campbell, D. T. 1979. Quasi-Experimentation: Design \& Analysis Issues for Field Settings. Boston, MA: Houghton Mifflin Company.

Cook, T. D., Campbell, D. T., \& Peracchio, L. 1990. Quasi Experimentation. In M. D. Dunnette, \& L. M. Hough (Eds.), Handbook of Industrial and Organizational Psychology, 2 ed., Vol. 1: 491-576. Palo Alto, CA: Consulting Psychologists Press.

Cui, G., \& Liu, Q. 2001. Executive Insights: Emerging Market Segments in a Transitional Economy: A Study of Urban Consumers in China. Journal of International Marketing, 9: 84-106.

Denzin, N., \& Lincoln, Y. 1998. Handbook of Qualitative Research. Thousand Oaks, CA: Sage.

Douglas, S. P., \& Wind, Y. 1987. The Myth of Globalization. Columbia Journal of World Business, 22: 19-29.

Financial Times. 1997, July 14th. Xerox Makes Copies. Financial Times: 10. 
Ghoshal, S., \& Westney, D. E. 1993. Organizational Theory and the Multinational Corporation. New York: St. Martin's Press.

Gielens, K., \& Dekimpe, M. G. 2001. Do International Entry Decisions of Retail Chains Matter in the Long Run? International Journal of Research in Marketing, 18: 235-259.

Great Harvest Bread. 1999. Apprenticeship Agreement: 2. Great Harvest Bread Co.

Griffith, D. A., Hu, M. Y., \& Ryans, J. K., Jr. 2000. Process Standardization across Intra and Inter-Cultural Relationships. Journal of International Business Studies, 31: 303-324.

Hannan, M. T., Burton, M.D., \& Baron, J. N. 1996. Inertia and Change in the Early Years: Employment Relations in Young, High-Technology Firms. Industrial and Corporate Change, 5: 503-536.

Hoaglin, D. C., Light, R. J., McPeek, B., Mosteller, F., \& Stoto, M. A. 1982. Data for Decisions: Information Strategies for Policymakers. Cambridge, Massachusetts: Abt Books.

Hofstede, G. 1997. Culture and Organizations: Software of the Mind. New York: McGrawHill.

Ilgen, D. R. 1986. Laboratory Research: A Question of When, Not If. In E. A. Locke (Ed.), Generalizing from Laboratory to Field Settings: Research Findings from IndustrialOrganizational Psychology, Organizational Behavior, and Human Resource Management: 257-266. Lexington, MA: Lexington Books.

Jensen, R.J., \& Szulanski, G. 2006. Templates and Knowledge Transfer: An Empirical Investigation of the Effectiveness of Template Use and the Mechanisms of Template Operation. Brigham Young University, working paper.

Kaufmann, P. J., \& Eroglu, S. 1998. Standardization and Adaptation in Business Format Franchising. Journal of Business Venturing, 14: 69-85.

King, G., Keohane, R., \& Verba, S. 1994. Designing Social Inquiry: Scientific Inference in Qualitative Research. Princeton, NJ: Princeton University Press.

Kirkman, B. L., Gibson, C. B., \& Shapiro, D. L. 2001. "Exporting" Teams: Enhancing the Implementation and Effectiveness of Work Teams in Global Affiliates. Organizational Dynamics, 30: 12-29.

Kostova, T. 1999. Transnational Transfer of Strategic Organizational Practices: A Contextual Perspective. Academy of Management Review, 24: 308-324.

Kostova, T., \& Roth, K. 2002. Adoption of an Organizational Practice by Subsidiaries of Multinational Corporations: Institutional and Relational Effects. Academy of Management Journal, 45: 215-233. 
Kostova, T., \& Zaheer, S. 1999. Organizational Legitimacy under Conditions of Complexity: The Case of the Multinational Enterprise. Academy of Management Review, 24: 64-81.

Lawrence, P., \& Lorsch, J. 1967. Organization and Environment. Boston, MA: Harvard University, Graduate School of Business Administration, Division of Research.

Leonard-Barton, D. 1988. Implementation as Mutual Adaptation of Technology and Organization. Research Policy, 17: 251-267.

Lippman, S. A., \& Rumelt, R. P. 1982. Uncertain Imitability: An Analysis of Interfirm Differences in Efficiency under Competition. Bell Journal of Economics, 13: 418-438.

Love, J. F. 1986. McDonald's: Behind the Arches. New York: Bantam Books.

Luo, Y. 2000. Determinants of Local Responsiveness: Perspectives from Foreign Subsidiaries in an Emerging Market. Journal of Management, 27: 451-477.

Mann L. 1977. The Effect of Stimulus Queues on Queue-Joining Behavior. Journal of Personality and Social Psychology, 35: 437-442.

McDonald, C. J. 1998. The Evolution of Intel's Copy Exactly! Technology Transfer Method. Intel Technology Journal:

http://www.intel.com/technology/itj/q41998/articles/art_41992.htm. Access date: 2003.

Morosini, P., Shane, S., \& Singh, H. 1998. National Cultural Distance and Cross-Border Acquisition Performance. Journal of International Business Studies, 29: 137-158.

Nelson, R., \& Winter, S. 1982. An Evolutionary Theory of Economic Change. Cambridge: Belknap Press.

Nohria, N., \& Ghoshal, S. 1997. The Differentiated Network. San Francisco: Jossey-Bass Publishers.

Onkvisit, S., \& Shaw, J. J. 1987. Standardized International Advertising: A Review and Critical Evaluation of the Theoretical and Empirical Evidence. Columbia Journal of World Business, 22: 43-55.

Penrose, E. T. 1959. The Theory of Growth of the Firm. London: Basil Blackwell.

Prahalad, C. K., \& Doz, Y. L. 1987. The Multinational Mission: Balancing Local Demands and Global Vision. New York: Free Press.

Prahalad, C. K., \& Lieberthal, K. 1998. The End of Corporate Imperialism. Harvard Business Review: 69-79. 
Rivkin, J. W. 2000. Imitation of Complex Strategies. Management Science, 46: 824-844.

Robert, C., Probst, T. M., Martocchio, J. J., \& Drasgow, F. 2000. Empowerment and Continuous Improvement in the United States, Mexico, Poland, and India: Predicting Fit on the Basis of the Dimensions of Power Distance and Individualism. Journal of Applied Psychology, 85: 643-658.

Rosenzweig, P. M., \& Nohria, N. 1994. Influences on Human Resource Management Practices in Multinational Corporations. Journal of International Business Studies, 25: 229-251.

Scott, W. R. 2001. Institutions and Organizations (2 ed.). Thousand Oaks, CA: Sage.

Seid, M., \& Thomas, D. 2000. Franchising for Dummies. Foster City, CA: IDG Books Worldwide.

Shadish, W. R., Cook, T. D., \& Campbell, D. T. 2002. Experimental and Quasi-Experimental Designs for Generalized Causal Inference. Boston: Houghton Mifflin.

Siggelkow, N. 2002. Evolution Toward Fit. Administrative Science Quarterly, 47: 125-159.

Sorge, A. 1991. Strategic Fit and the Societal Effect: Interpreting Cross-National Comparisons of Technology, Organization and Human Resources. Organization Studies, 12: 161-190.

Szulanski, G. 1996. Exploring Internal Stickiness: Impediments to the Transfer of Best Practice within the Firm. Strategic Management Journal, 17: 27-43.

Tyre, M. J., \& Orlikowski, W. J. 1994. Windows of Opportunity: Temporal Patterns of Technological Adaptation in Organization. Organization Science, 5: 98-118.

Tolbert, P.S. and L. G. Zucker. 1983). Institutional Sources of Change in the Formal Structure of Organizations: The Diffusion of Civil Service Reforms, 1880-1935. Administrative Science Quarterly, 23: 22-39.

von Hippel, E. 1994. "Sticky Information" and the Locus of Problem Solving: Implications for Innovation. Management Science, 40: 429-439.

Westney, D. E. 1987. Imitation and Innovation: The Transfer of Western Organizational Patterns to Meiji Japan (First ed.). Cambridge, Massachusetts: Harvard University Press.

Westphal, J. D., Gulati, R., \& Shortell, S. M. 1997. Customization and Conformity: An Institutional and Network Perspective on the Content and Consequences of TQM Adoption. Administrative Science Quarterly, 366-394.

Williamson, O. E. 1975. Markets and Hierarchies: Analysis and Antitrust Implications. New York: The Free Press. 
Winter, S. G., \& Szulanski, G. 2001. Replication as Strategy. Organization Science, 12: 730743.

Yan, R. 1994. To Reach China's Consumers, Adapt to Guo Qing. Harvard Business Review: 6674.

Yin, R. K. 1989. Case Study Research (Revised ed.). Newbury Park, California: Sage.

\section{APPENDIX A}

\begin{tabular}{lc}
\hline Persons Interviewed, by Job Title & Number \\
\hline MBE Headquarters, San Diego, CA, USA & 1 \\
CEO & 1 \\
Executive Vice President in charge of Sales & 1 \\
Director of International Operations & 1 \\
Director of International Sales & 1 \\
Director of International Franchise Business Development & 1 \\
Director of International Training & 2 \\
MBE Israel Headquarters, Tel Aviv, Israel & 1 \\
CEO & 1 \\
COO & 1 \\
Director of Operations & 1 \\
Assistant Director of Operations & 4 \\
Director of Marketing & 2 \\
Franchisees in Israeli Network & \\
Suppliers of Israeli Network &
\end{tabular}

\section{APPENDIX B}

The MBE statement of culture and core values reproduced below (italics added for emphasis) can be found at the following web address: http://www.mbe.com/ambe/cacu.html.

\section{MBE Culture}

At MBE, we pride ourselves on maintaining an atmosphere of teamwork and camaraderie, a spirit that permeates our entire corporate culture. For this reason, we refer to the collective network of MBE corporate employees and franchisees as the MBE Family.

We understand the importance of a comfortable work environment that fosters growth, both personally and professionally. Our primary goal is to focus on customer intimacy while adhering to our core values of caring, honesty, fairness, integrity, trust, respect, commitment and accountability. A shared mission and core values are the heart and soul of the Mail Boxes Etc. culture. The MBE mission statement and core values have permanence because they grew out of a collaborative process that included every member of the MBE corporate office team. 


\section{Our Mission Statement}

Making business easier worldwide through our service and distribution network, delivering personalized and convenient business solutions with world-class customer service.

\section{Our Core Values}

Respect, Accountability, Fairness, Trust, Caring, Commitment, Honesty and Integrity

Likewise, the officers who comprise the MBE Leadership Council wholeheartedly embrace the concept of "servant leadership" in their dealings with members of the MBE family. They, too, recognize that when we treat one another as "customers" we create an environment in which mutually beneficial relationships are developed and nurtured. 